\title{
IMPROVING FRUIT QUALITY OF WONDERFUL POMEGRANATE BY USING FOLIAR APPLICATION OF POTASSIUM, IRON AND BORON
}

\author{
Hamdy, I.M. Ibrahim ${ }^{1}$, Mohamed M. Ibrahim ${ }^{2 *}$ and Moustafa O.A. Omar ${ }^{1}$ \\ ${ }^{1}$ Hort. Dept., Fac. Agric., Minia Univ., Egypt \\ ${ }^{2}$ Hort. Dept., Fac. Agric., Zagazig Univ., Egypt
}

*Corresponding author: mmnasr@zu.edu.eg

Received:20August 2019 ;Accepted:18 Sept. 2019

\begin{abstract}
This study was carried out during 2017 and 2018 seasons, in order to investigate the effect of single and combined application of potassium sulphate $\left(\mathrm{K}_{2} \mathrm{SO}_{4}\right)$, ferrous sulphate $\left(\mathrm{FeSO}_{4}\right)$ and boric acid $\left(\mathrm{H}_{3} \mathrm{BO}_{3}\right)$ on fruit physical, chemical properties and maturation of Wonderful pomegranate trees grown in sandy soil under Minia Governorate conditions. Results showed that increasing the concentration of $\mathrm{K}_{2} \mathrm{SO}_{4}$ from 0.5 to $1.5 \%, \mathrm{FeSO}_{4}$ from 100 to $200 \mathrm{ppm}$ or/and $\mathrm{H}_{3} \mathrm{BO}_{3}$ was very effective in fruit weight $(\mathrm{g})$. While, the three examined compounds significantly decreased fruit cracked $(\%)$ and fruit sunburned (\%) during the two experimental season. Application of the three examined compounds together significantly surpassed than untreated control or each compound alone terms of improved fruit physical and chemical properties, while, juice total acidity was significantly decreased. For producing favorable fruit physical properties of Wonderful pomegranate grown under sandy soil, it is necessary to spray the trees with mixture of potassium sulphate at $1.5 \%$, ferrous sulphate at $200 \mathrm{ppm}$ and boric acid at $100 \mathrm{ppm}$ three times yearly during the fruit growth cycle.
\end{abstract}

Key words: Wonderful pomegranate, quality, potassium, iron, boron, fruit cracked and sunburned.

\section{INTRODUCTION}

Pomegranate is a highly valuated fruit crop for its health-promoting effects and it is mainly cultivated in semi-arid areas (Catola et al., 2016). Wonderful is a newly introduced pomegranate cultivar grown under Egyptian condition, still needs additional studies about fruit ripening and quality. This cultivar has great advantages and good opportunity to succeed under Egyptian conditions due to its tolerance to drought, salinity and various pests, besides the disappearance of fruit cracking. On the other hand, some recent trials carried out under Minia Governorate conditions noted that the some important parameters of wonderful fruits, such as fruit and grains colour remarkably decreased as a compared to the local cultivar "Manfalouty" (Omar, 2015 and Abo-Ali, 2019). The total acreage of pomegranate in Egypt reached 34450 fad. out of them 11752 fad., is fruitful producing about 106260 tons with an average of 9.42 tons/ fad. (Statistics of the Ministry of Agriculture, 2015).

Improving the most important quality parameter of fruit is the foundation for success in producing pomegranate fruits. A wide range of environmental and genetic factors affects pomegranate fruits quality, where nutrition plays an important role. Potassium (K), ferrus ( $\mathrm{Fe}$ ) and boron (B) are the key nutritional factors controlling fruit development and maturation (Marschner, 1995).

Potassium is an essential plant element that has important influence on many vital functions like carbon assimilation, translocation of proteins and sugars, enhancing fruit quality by maintaining desirable TSS/ acid ratio and ripening of fruit. Thus, it is the most important mineral regulating the quality of fruit by helping to move starches and sugars between plant parts (Lavon and Goldschmidt, 1996, Kumar et al., 2006 and Ganeshamurthy et al., 2011). In addition to the role of potassium in plant tolerance of biotic and abiotic stress Mengl (1985); Marschner (1997); Havlin et al., (2005); Khalil and Aly (2013); Kow and Nabwami (2015) and Abo-Ali (2019).

Iron plays a fundamental role in several physiological processes. Iron is the third most limiting nutrient for plant growth and metabolism, 
primarily due to the low solubility of the oxidized ferric form in aerobic environments (Zuo and Zhang, 2011; Samaranayke et al., 2012). Particularly in fruit crops, Fe deficiency causes serious decreases in tree growth, fruit yield, and quality (Tagliavini et al., 2000). Iron uptake by plants is fastest when iron is present in the ferrous form (Chaney et al., 1972).

Foliar B application to $\mathrm{B}$ deficient trees increases $\mathrm{Ca}$ mobility as well as $\mathrm{Ca}$ concentration of the fruit (Shear and Faust, 1971). Boron is an essential trace element required for optimal growth and development of higher plants and B shortage is believed to be the most widespread of micronutrient deficiencies in plants (Sparr, 1970). Production of fruit crops is adversely affected much more than vegetative growth with a low supply of available B in soil. Boron amelioration of fruit quality could be directly or indirectly related to an interaction of B and cation nutrition (Davis et al., 2003).

The current investigation aimed to examine the Wonderful pomegranate fruit quality responses of foliar sprayusing potassium, iron and boron in sandy soil under Minia Governorate conditions.

\section{MATERIALS AND METHODS}

The present investigation was conducted during two seasons 2017 and 2018 on one hundred-eight uniform in vigor Wonderful pomegranate trees grown in private orchard located at the Cairo-Assiut Eastern Desert Road, facing Minia Distract, ElMinia Governorate (250 km southern Cairo city), Egypt where the soil texture is sandy and water table depth is not less than two meters. The chosen pomegranate trees are ten-years old and planted at 4 $\mathrm{x} 4$ meters apart and irrigated by drip system using underground well. The formation of the chosen trees is multi trunk ( 3 trunk/tree) an open vase system with 4 to 6 principal branches and at least two principal layers of production. Winter pruning was followed at the first week of January.

The chosen trees are subjected to regular horticulture practices that were commonly applied in the orchard including fertilization, (namely: 80 $\mathrm{g} /$ tree nitrogen applied in the form of ammonium nitrate $\quad 33 \% \quad \mathrm{~N}$ ", $245 \mathrm{~kg} /$ feddan, calcium superphosphate "15.5\% $\mathrm{P}_{2} \mathrm{O}_{5} " 200 \mathrm{~kg} /$ feddan and $150 \mathrm{~kg} /$ feddan potassium sulphate, as well as irrigation, hoeing and pest management.

A composite sample of experiment soil collected and subjected to Physical and chemical analysis according to the procedures outlined by Walsh and Beaton (1986). The data of soil sample analyses are shown in Table (1).
Table 1. Physical and chemical analysis of experiment soil

\begin{tabular}{lc}
\hline \multicolumn{1}{c}{ Constituents } & Values \\
\hline Sand \% & 79.4 \\
Silt \% & 12.50 \\
Clay \% & 8.10 \\
Texture & Sandy \\
EC $(1: 2.5$ extract) mmhos/cm & 5.20 \\
Organic matter \% & 0.45 \\
$\mathrm{pH}(1: 2.5$ extract) & 8.29 \\
$\mathrm{CaCO}(\%)$ & 9.00 \\
$\mathrm{~N}(\mathrm{mg} / \mathrm{kg})$ & 185.00 \\
Phosphorus (ppm) & 8.80 \\
Available Ca (meq/100g) & 19.90 \\
Available $\mathrm{Mg}(\mathrm{meq} / 100 \mathrm{~g})$ & 2.33 \\
Available $\mathrm{K}(\mathrm{meq} / 100 \mathrm{~g})$ & 0.56 \\
$\mathrm{C} / \mathrm{N}$ Ratio & 17.20 \\
\hline
\end{tabular}

In order to study the effect and the suitable concentration of spraying $\mathrm{K}_{2} \mathrm{SO}_{4}$ (potassium sulphate), $\mathrm{FeSO}_{4}$ (Ferrous sulphate) and $\mathrm{H}_{3} \mathrm{BO}_{3}$ (Boric acid) compounds were tested on Wonderful pomegranate. $\mathrm{K}_{2} \mathrm{SO}_{4}$ was sprayed at four concentrations namely $0.0,0.5,1.0$ and $1.5 \%$ single or companied with $\mathrm{FeSO}_{4}$ at $100 \& 200 \mathrm{ppm}$ or/and $\mathrm{H}_{3} \mathrm{BO}_{3}$ at 50 \& $100 \mathrm{ppm}$ were tested on Wonderful pomegranate cultivar of the present experiment. The trees were sprayed with $\mathrm{K}_{2} \mathrm{SO}_{4}$ on the first of April, May and June, while $\mathrm{FeSO}_{4}$ and $\mathrm{H}_{3} \mathrm{BO}_{3}$ on mid of April, May and June each season.

This experiment included thirty six treatments from two factors and its interactions. The first factor (A) comprised from four $\mathrm{K}_{2} \mathrm{SO}_{4}$ concentrations. The second factor (B) comprised from nine concentrations of $\mathrm{FeSO}_{4}$ and $\mathrm{H}_{3} \mathrm{BO}_{3}$. Each treatment was replicated three times, one tree per each. Then the present study included one hundred eight trees. Treatments were arranged in a complete randomized block in a split plot design (the factor A ranked in main plot and the factor B ranked in split plot). Triton B (at $0.05 \mathrm{~g} /$ liter) as a wetting agent was added to all spraying solutions, even control trees.

The responses of the tested trees to foliar spray treatments were evaluated through the following parameters:

Fruit physical properties: The fruits were harvested when fruits become fully colored and the TSS/acid ratio in the juice of the check treatment reached 3 to 3.5 in the two experimental seasons. The percentage of cracking fruits and sunburned fruits per tree were recorded as follow:

$$
\begin{aligned}
& \begin{array}{l}
\text { Cracking } \\
\text { fruits } \%
\end{array}=\frac{\text { No. of cracked fruits/tree }}{\text { Total no. of fruits/tree }} \times 100 \\
& \begin{array}{c}
\text { Sunburned } \\
\text { fruits } \%
\end{array}=\frac{\text { No. of sunburned fruits/tree }}{\text { Total no. of fruits/tree }} \times 100
\end{aligned}
$$


From each tree, five fruits/ tree were randomly picked at maturation date (Last week of September) to estimate the physio-chemical characteristics of fruits as follows:

- Fruit weight (g).

- Fruit dimension [length (L) and diameter (D) $(\mathrm{cm})$ ] by using Vernier caliper.

- Peel thickness (cm).

- Grains weight and Juice weight percentages (\%), mathematically calculated according the following equations:

$$
\begin{array}{llll}
\begin{array}{c}
\text { Grains } \\
\text { weight } \%
\end{array} & =\frac{\text { Fruit grains weight }(\mathrm{g})}{\text { Fruit weight }(\mathrm{g})} \times & 100 \\
\begin{array}{c}
\text { Juice } \\
\text { weight } \%
\end{array} & =\frac{\text { Fruit juice weight }(\mathrm{g})}{\text { Fruit grains weight }(\mathrm{g})} \times & 100
\end{array}
$$

Chemical characteristics of juice: After extracting the arils by hand, $200 \mathrm{~g}$ of each replicate were randomly chosen from homogenized sample, pressed by Electric Extractor for extracting the juice, the following chemical characteristics were determined:

- Total soluble solids (TSS \%) was determined in juice using a hand refractometer.

- Total titratable acidity (TA \%), expressed as grams citric acid per $100 \mathrm{~g}$ of juice, by titration against $0.1 \mathrm{~N} \mathrm{NaOH}$ solution, using $1 \mathrm{ml}$ diluted juice in $10 \mathrm{ml}$ distilled $\mathrm{H} 2 \mathrm{O}$ in the presence of phenolphythalein index as indicator and the total acidity percentage was calculated (A.O.A.C., 2006).

- Reducing and non-sugars percentages in the juice, determined by using Lane and Eynone volumetric method, according to Ranganna (1977).

- Total anthocyanin content in peel and fruit juice was estimatedaccording to the methods described by Geza et al (1983).

Statistical analysis: All the obtained data were tabulated and subjected to analysis of variance (ANOVA) according to Snedecor and Cochran (1980) by using the statistical package MSTAT program. Comparisons between means were made by the F-test and least significant differences (New L.S.D) at $\mathrm{P}$ value $\leq 5 \%$ level.

\section{RESULTS AND DISCUSSION}

\section{Fruit physical properties}

\section{Fruit weight (g)}

It is noticed from the obtained data in Table (2) that, treating Wonderful pomegranate trees with $\mathrm{K}_{2} \mathrm{SO}_{4}$ (at $0.05 \%$ to $1.5 \%$ ), $\mathrm{FeSO}_{4}$ (at 100 and 200 ppm), and $\mathrm{H}_{3} \mathrm{BO}_{3}$ (at 50 and $100 \mathrm{ppm}$ ) had significantly improved the fruit weight in the two seasons compared with untreated trees. The trees were sprayed with high concentration of $\mathrm{K}_{2} \mathrm{SO}_{4}$ $(1.5 \%)$ recorded highest fruit weight $(\mathrm{g})$ compared to untreated trees with any compound which gave the least values in the two seasons.

The interactions between $\mathrm{K}_{2} \mathrm{SO}_{4}, \mathrm{FeSO}_{4}$, and $\mathrm{H}_{3} \mathrm{BO}_{3}$ treatments were significant on fruit weight $(\mathrm{g})$ in the two seasons. The highest fruit weight (449 and $431 \mathrm{~g}$ ) was produced from spraying trees with $\mathrm{K}_{2} \mathrm{SO}_{4}$ at higher level $(1.5 \%)$ in combination with $\mathrm{FeSO}_{4}$ at 200 ppm plus $\mathrm{H}_{3} \mathrm{BO} 3$ at 100 ppm. While, the least values were recorded from trees sprayed with $\mathrm{K}_{2} \mathrm{SO}_{4}$ at $0.0 \% \times \mathrm{H}_{3} \mathrm{BO}_{3}$ and $\mathrm{FeSO}_{4}$ at $0.0 \mathrm{ppm}$ $(329 \mathrm{~g})$ in the first season and those sprayed with $\mathrm{K}_{2} \mathrm{SO}_{4}$ at $0.0 \% \times \mathrm{H}_{3} \mathrm{BO}_{3}$ at $50 \mathrm{ppm}$ and $0.0 \mathrm{ppm}$ $\mathrm{FeSO}_{4}(335 \mathrm{~g})$ in the second one.

The obtained results concerning the effect of $\mathrm{K}$, $\mathrm{Fe}$ and $\mathrm{B}$ on fruit weight are in accordance with those obtained by Mengle, 2007; Omar (2015); Ibrahim and Al-Wasfy (2014); Mohamed (2014) and Abo-Ali (2019).

\section{Fruit dimensions}

The data in Table (2) showed that fruit length and diameter significantly improved with using $\mathrm{K}_{2} \mathrm{SO}_{4}, \mathrm{FeSO}_{4}$ and $\mathrm{H}_{3} \mathrm{BO}_{3}$ either applied singly or used in different combinations compared with untreated control. Remarkable and gradual Increasing in fruit length and diameter were parallel to increasing potassium sulphate concentration from 0.0 to $1.5 \%$. Combined application of the three examined compounds was preferable than using each compound alone in enhancing fruit length and diameter $(\mathrm{cm})$. However, the highest values of fruit length $(8.12 \& 7.99 \mathrm{~cm})$ and fruit diameter $(7.27$ $\& 7.33 \mathrm{~cm}$ ) were produced in the trees treated with $\mathrm{K}_{2} \mathrm{SO}_{4}$ at $1.5 \%, \mathrm{FeSO}_{4}$ at $200 \mathrm{ppm}$ and $\mathrm{H}_{3} \mathrm{BO}_{3}$ at 100 $\mathrm{ppm}$.

The beneficial effect of potassium, iron and boron on the biosynthesis and translocation of carbohydrates as well as $\mathrm{N}$ metabolism and activation some important enzymes could be explained improving fruit length and diameter (Marschner, 1997; Mengel, 2007 and Abd ElGabber, 2009). 
Table 2. Effect of spraying potassium sulphate, ferrous sulphate, and boric acid on fruit weight (g), fruit length (cm) and fruit diameter $(\mathrm{cm})$ of Wonderful pomegranate fruits during 2017 and 2018 seasons

\begin{tabular}{|c|c|c|c|c|c|c|c|c|c|c|c|c|c|c|c|}
\hline \multirow{3}{*}{ Treatments } & \multicolumn{5}{|c|}{ Fruit weight (g) } & \multicolumn{5}{|c|}{ Fruit length $(\mathrm{cm})$} & \multicolumn{5}{|c|}{ Fruit diameter $(\mathrm{cm})$} \\
\hline & \multicolumn{5}{|c|}{ First Season (2017) } & \multicolumn{5}{|c|}{ First Season (2017) } & \multicolumn{5}{|c|}{ First Season (2017) } \\
\hline & $\begin{array}{c}\mathrm{K}_{2} \mathbf{S O}_{4} \\
\mathbf{0 . 0 \%} \\
\end{array}$ & $\begin{array}{c}\mathrm{K}_{2} \mathrm{SO}_{4} \\
0.5 \% \\
\end{array}$ & $\begin{array}{c}\mathrm{K}_{2} \mathrm{SO}_{4} \\
1.0 \% \\
\end{array}$ & $\begin{array}{c}\mathrm{K}_{2} \mathrm{SO}_{4} \\
1.5 \% \\
\end{array}$ & $\begin{array}{c}\text { Mean } \\
\text { B } \\
\end{array}$ & $\begin{array}{c}\mathrm{K}_{2} \mathrm{SO}_{4} \\
0.0 \%\end{array}$ & $\begin{array}{c}\mathrm{K}_{2} \mathrm{SO}_{4} \\
0.5 \% \\
\end{array}$ & $\begin{array}{c}\mathrm{K}_{2} \mathrm{SO}_{4} \\
1.0 \% \\
\end{array}$ & $\begin{array}{c}\mathrm{K}_{2} \mathrm{SO}_{4} \\
1.5 \% \\
\end{array}$ & $\begin{array}{c}\text { Mean } \\
\text { B }\end{array}$ & $\begin{array}{c}\mathrm{K}_{2} \mathrm{SO}_{4} \\
\mathbf{0 . 0 \%}\end{array}$ & $\begin{array}{c}\mathrm{K}_{2} \mathrm{SO}_{4} \\
0.5 \% \\
\end{array}$ & $\begin{array}{c}\mathrm{K}_{2} \mathrm{SO}_{4} \\
1.0 \% \\
\end{array}$ & $\begin{array}{c}\mathrm{K}_{2} \mathrm{SO}_{4} \\
1.5 \% \\
\end{array}$ & $\begin{array}{c}\text { Mean } \\
\text { B }\end{array}$ \\
\hline Fe $0.0+B ~ 0.0 \mathrm{ppm}$ & 329.00 & 339.00 & 365.00 & 374.00 & 351.80 & 6.89 & 6.94 & 7.11 & 7.20 & 7.04 & 6.39 & 6.48 & 6.47 & 6.49 & 6.46 \\
\hline Fe 100 ppm + B 0.0 ppm & 359.00 & 365.00 & 371.00 & 389.00 & 371.00 & 6.90 & 7.08 & 7.14 & 7.29 & 7.10 & 6.45 & 6.56 & 6.71 & 6.79 & 6.63 \\
\hline Fe 200 ppm + B 0.0 ppm & 369.00 & 388.00 & 403.00 & 412.00 & 393.00 & 7.17 & 7.17 & 7.28 & 7.32 & 7.24 & 6.48 & 6.66 & 6.83 & 6.91 & 6.72 \\
\hline B 50 ppm + Fe 0.0 ppm & 345.00 & 361.00 & 387.00 & 389.00 & 370.50 & 6.90 & 6.99 & 7.19 & 7.23 & 7.08 & 6.33 & 6.50 & 6.69 & 6.71 & 6.65 \\
\hline B 100 ppm + Fe 0.0 ppm & 349.00 & 379.00 & 399.00 & 403.00 & 382.50 & 7.03 & 7.19 & 7.23 & 7.28 & 7.18 & 6.45 & 6.59 & 6.78 & 6.83 & 6.66 \\
\hline Fe $100+$ B 50 ppm & 369.00 & 387.00 & 392.00 & 415.00 & 390.80 & 7.25 & 7.41 & 7.69 & 7.77 & 7.53 & 6.69 & 6.72 & 6.81 & 6.71 & 6.73 \\
\hline Fe 100 ppm + B 100 ppm & 377.00 & 411.00 & 409.00 & 414.00 & 402.80 & 7.42 & 7.76 & 7.77 & 7.89 & 7.71 & 6.71 & 6.74 & 6.88 & 6.92 & 6.81 \\
\hline Fe 200 ppm + B 50 ppm & 389.00 & 420.00 & 431.00 & 439.00 & 419.80 & 7.58 & 7.80 & 7.84 & 7.99 & 7.80 & 6.92 & 7.03 & 7.19 & 7.19 & 7.08 \\
\hline Fe 200 ppm + B 100 ppm & 406.00 & 423.00 & 443.00 & 449.00 & 430.30 & 7.69 & 7.77 & 7.93 & 8.12 & 7.88 & 6.82 & 7.09 & 7.25 & 7.27 & 7.13 \\
\hline Mean A & 365.30 & 384.90 & 400.00 & 409.30 & & $\mathbf{7 . 2 0}$ & 7.35 & 7.46 & 7.57 & & 6.59 & 6.71 & 6.84 & 6.87 & \\
\hline New LSD $5 \%$ & \multicolumn{2}{|c|}{$A=13.20 ;$} & $B=15.30$ & \multicolumn{2}{|c|}{; $\mathbf{A B}=\mathbf{2 2 . 3 0}$} & \multicolumn{5}{|c|}{$\mathrm{A}=0.03 ; \mathrm{B}=0.05 ; \mathrm{AB}=0.07$} & \multicolumn{5}{|c|}{$A=0.04$} \\
\hline \multirow{2}{*}{ Treatments } & \multicolumn{5}{|c|}{ Second Season (2018) } & \multicolumn{5}{|c|}{ Second Season (2018) } & \multicolumn{5}{|c|}{ Second Season (2018) } \\
\hline & $\begin{array}{c}\mathrm{K}_{2} \mathbf{S O}_{4} \\
\mathbf{0 . 0 \%} \\
\end{array}$ & $\begin{array}{c}\mathrm{K}_{2} \mathrm{SO}_{4} \\
0.5 \% \\
\end{array}$ & $\begin{array}{c}\mathrm{K}_{2} \mathrm{SO}_{4} \\
1.0 \% \\
\end{array}$ & $\begin{array}{c}\mathrm{K}_{2} \mathrm{SO}_{4} \\
1.5 \% \\
\end{array}$ & $\begin{array}{c}\text { Mean } \\
\text { B } \\
\end{array}$ & $\begin{array}{c}\mathrm{K}_{2} \mathrm{SO}_{4} \\
0.0 \% \\
\end{array}$ & $\begin{array}{c}\mathrm{K}_{2} \mathrm{SO}_{4} \\
0.5 \% \\
\end{array}$ & $\begin{array}{c}\mathrm{K}_{2} \mathrm{SO}_{4} \\
1.0 \% \\
\end{array}$ & $\begin{array}{c}\mathrm{K}_{2} \mathrm{SO}_{4} \\
1.5 \% \\
\end{array}$ & $\begin{array}{c}\text { Mean } \\
\text { B } \\
\end{array}$ & $\begin{array}{c}\mathrm{K}_{2} \mathrm{SO}_{4} \\
0.0 \% \\
\end{array}$ & $\begin{array}{c}\mathrm{K}_{2} \mathrm{SO}_{4} \\
0.5 \% \\
\end{array}$ & $\begin{array}{c}\mathrm{K}_{2} \mathrm{SO}_{4} \\
1.0 \% \\
\end{array}$ & $\begin{array}{c}\mathrm{K}_{2} \mathrm{SO}_{4} \\
1.5 \% \\
\end{array}$ & $\begin{array}{c}\text { Mean } \\
\text { B }\end{array}$ \\
\hline Fe 0.0 + B 0.0 ppm & 339.00 & 349.00 & 355.00 & 364.00 & 351.80 & 6.79 & 6.81 & 6.88 & 6.91 & 6.85 & 6.36 & 6.49 & 6.51 & 6.62 & 6.50 \\
\hline Fe 100 ppm + B 0.0 ppm & 348.00 & 355.00 & 371.00 & 389.00 & 365.80 & 6.89 & 6.98 & 7.15 & 7.21 & 7.06 & 6.49 & 6.66 & 6.72 & 6.82 & 6.67 \\
\hline Fe 200 ppm + B 0.0 ppm & 359.00 & 378.00 & 403.00 & 412.00 & 388.00 & 6.99 & 7.08 & 7.29 & 7.33 & 7.17 & 6.52 & 6.69 & 6.91 & 6.97 & 6.77 \\
\hline B 50 ppm + Fe 0.0 ppm & 335.00 & 355.00 & 387.00 & 389.00 & 366.50 & 6.82 & 6.93 & 7.19 & 7.22 & 7.04 & 6.43 & 6.57 & 6.72 & 6.72 & 6.61 \\
\hline B 100 ppm + Fe 0.0 ppm & 340.00 & 369.00 & 389.00 & 398.00 & 374.00 & 6.93 & 7.19 & 7.21 & 7.37 & 7.18 & 6.49 & 6.69 & 6.77 & 6.89 & 6.71 \\
\hline Fe $100+$ B 50 ppm & 352.00 & 377.00 & 390.00 & 406.00 & 380.80 & 7.09 & 7.26 & 7.49 & 7.51 & 7.34 & 6.71 & 6.79 & 6.92 & 6.77 & 6.80 \\
\hline Fe 100 ppm + B 100 ppm & 362.00 & 399.00 & 411.00 & 418.00 & 397.50 & 7.19 & 7.39 & 7.51 & 7.61 & 7.43 & 6.78 & 6.82 & 6.99 & 7.12 & 6.93 \\
\hline Fe 200 ppm + B 50 ppm & 377.00 & 401.00 & 421.00 & 429.00 & 407.00 & 7.45 & 7.65 & 7.88 & 7.91 & 7.72 & 6.86 & 7.11 & 7.18 & 7.22 & 7.09 \\
\hline Fe 200 ppm + B 100 ppm & 381.00 & 412.00 & 429.00 & 431.00 & 413.30 & 7.58 & 7.77 & 7.85 & 7.99 & 7.80 & 6.99 & 7.16 & 7.29 & 7.33 & 7.19 \\
\hline Mean A & 354.80 & 377.20 & 395.10 & 404.00 & & 7.08 & 7.23 & 7.38 & 7.45 & & 6.63 & $\mathbf{7 . 7 8}$ & 6.89 & 6.94 & \\
\hline New LSD 5\% & \multicolumn{5}{|c|}{$A=14.40 ; B=13.90 ; A B=20.30$} & \multicolumn{2}{|c|}{$\mathrm{A}=\mathbf{0 . 0 5}$} & $B=0.06$ & $\mathbf{A B}=\mathbf{0}$ & & \multicolumn{2}{|c|}{$\mathbf{A}=\mathbf{0 . 0 2}$} & $B=0.05$ & ; $\mathbf{A B}=$ & \\
\hline
\end{tabular}




\section{Fruit peel thickness (mm)}

The obtained data in Tables (3) showed that single or combined application of $\mathrm{K}_{2} \mathrm{SO}_{4}, \mathrm{FeSO}_{4}$ and $\mathrm{H}_{3} \mathrm{BO}_{3}$ caused a significant decrement of peel thickness $(\mathrm{mm})$ relative to the control treatment in the two seasons. Increasing potassium sulphate concentration from $1.0 \%$ to $1.5 \%$ had a negligible effect on fruit peel thickness. The least peel thickness was from $\mathrm{K}_{2} \mathrm{SO}_{4}$ at $1.5 \%(0.36 \& 0.30 \mathrm{~cm})$ in the first and second seasons, respectively.

However, combined application of $\mathrm{FeSO}_{4}$ at 200 ppm and $\mathrm{H}_{3} \mathrm{BO}_{3}$ at $100 \mathrm{ppm}$ were preferable than using each compound alone in reducing peel thickness. Furthermore, these decrements were clearer for boric acid separation than those of ferrous sulphate. Using both compounds together significantly surpassed the application of each compound alone in this concentration. However, the lowest peel thickness values were recorded on the trees that received both materials together at highest concentrations $(0.35$ and $0.34 \mathrm{~cm})$ in the both seasons, respectively. In the contrary, untreated trees, the maximum produced values.

The interaction between potassium sulphate, ferrous sulphate and boric acid had significant effect on peel thickness of Wonderful pomegranate fruits. Treating the trees with potassium sulphate at $1.5 \%$, ferrous sulphate at $200 \mathrm{ppm}$ and boric acid at 100 ppm give the minimum values of fruit peel thickness $(0.31$ and $0.30 \mathrm{~cm})$ compared with untreated trees which recorded the highest values $(0.59 \& 0.58 \mathrm{~cm})$ during the two seasons respectively.

\section{Grains weight (\%)}

Data in Table (3) showed that concerning the three examined compounds were capable of causing significant promotion in average grains weight $\%$ of fruit over the control treatment in the two seasons.

Gradual promotion on average grains weight was associated with increasing potassium sulphate from 0.0 to $1.5 \%$. However, the higher concentration of potassium sulphate remarkably and significantly enhanced grains weight percentage than the lower concentrations. The data takes the similar trend during the two seasons. Except those between the two highest concentration of potassium sulphate (namely $1.0 \%$ and $1.5 \%$ ) during the second season, however non-significant differences were observed.

Subjecting Wonderful pomegranate trees three times of different concentration of $\mathrm{FeSO}_{4}$ or/and $\mathrm{H}_{3} \mathrm{BO}_{3}$ significantly were responsible for enhancing the percentage grains weight/fruit rather than the chick treatment. There was a gradual promotion on grains weight $\%$ with increasing concentrations of $\mathrm{FeSO}_{4}$ from 100 to 200 ppm or/and $\mathrm{H}_{3} \mathrm{BO}_{3}$ from 50 to $100 \mathrm{ppm}$. However, regardless the concentration used the combined application of $\mathrm{FeSO}_{4}$ and $\mathrm{H}_{3} \mathrm{BO}_{3}$ exhibited more effective on grains weight $\%$ than sprayed each one alone.

Regarding the interactions between the three examined compounds, increasing potassium sulphate concentration companied with ferrous sulphate or/and boric acid enhanced grains weight $\%$ significantly during the two seasons. Furthermore, the highest grains weight $\%(68.8 \%$ and $61.1 \%)$ were obtained from the fruit of the trees received potassium sulphate at $1.5 \%$ accompanied with $\mathrm{FeSO}_{4}$ at 200 ppm and $\mathrm{H}_{3} \mathrm{BO}_{3}$ at 100 ppm in the two seasons respectively. While, unfavorable effects on grains weight $\%$ (53.4\% and $50.2 \%$ ), during the two experimental seasons respectively, were produced by untreated trees.

\section{Juice weight percentage (\%)}

The obtained data in Table (3) shows that, the three examined compounds were capable of causing significant promotion in fruit juice weight $\%$ over the control treatment, during the two experimental seasons. Gradual promotion on average juice weight $\%$ was associated with increasing $\mathrm{K}_{2} \mathrm{SO}_{4}$ from 0.0 to $1.5 \%$. However, the higher concentration remarkably and significantly enhanced juice weight percentage than the lower one. Except those between the two highest concentration of potassium sulphate (namely $1.0 \%$ and $1.5 \%$ ) during the two seasons, however non-significant enhancement were observed between them. Subjecting trees to $\mathrm{H}_{3} \mathrm{BO}_{3}$ at 50 or $100 \mathrm{ppm}$ significantly was responsible for enhancing the percentage juice weight $\%$, rather than the untreated control. While, increasing $\mathrm{FeSO}_{4}$ concentration from $100 \mathrm{ppm}$ to $200 \mathrm{ppm}$ failed to vary the juice weight $\%$ significantly during the two experimental seasons. Further, regardless the concentration used the combined application of $\mathrm{FeSO}_{4}$ and $\mathrm{H}_{3} \mathrm{BO}_{3}$ exhibited more effective on juice weight $\%$ than sprayed each one alone.

Regarding the interactions between the three examined compounds, increasing $\mathrm{K}_{2} \mathrm{SO}_{4}$ concentration companied with $\mathrm{FeSO}_{4}$ and $\mathrm{H}_{3} \mathrm{BO}_{3}$ enhanced juice weight $\%$ significantly during the two seasons. However, the highest juice weight $\%$ (50.9 and $47.1 \%$ ) were obtained from the trees received potassium sulphate at $1.5 \%$ accompanied with $\mathrm{FeSO}_{4}$ at $200 \mathrm{ppm}$ and $\mathrm{H}_{3} \mathrm{BO}_{3}$ at $100 \mathrm{ppm}$ in the two experimental seasons respectively. While, unfavorable effects on juice weight $\%$ (36.0 and 36.2 $\%$ ), during the two experimental seasons respectively, were produced by untreated trees. 
Table 3. Effect of spraying potassium sulphate, ferrous sulphate, and boric acid on fruit peel thickness (cm), grains weight \% and Juice weight \% of Wonderful pomegranate fruits during 2017 and 2018 seasons

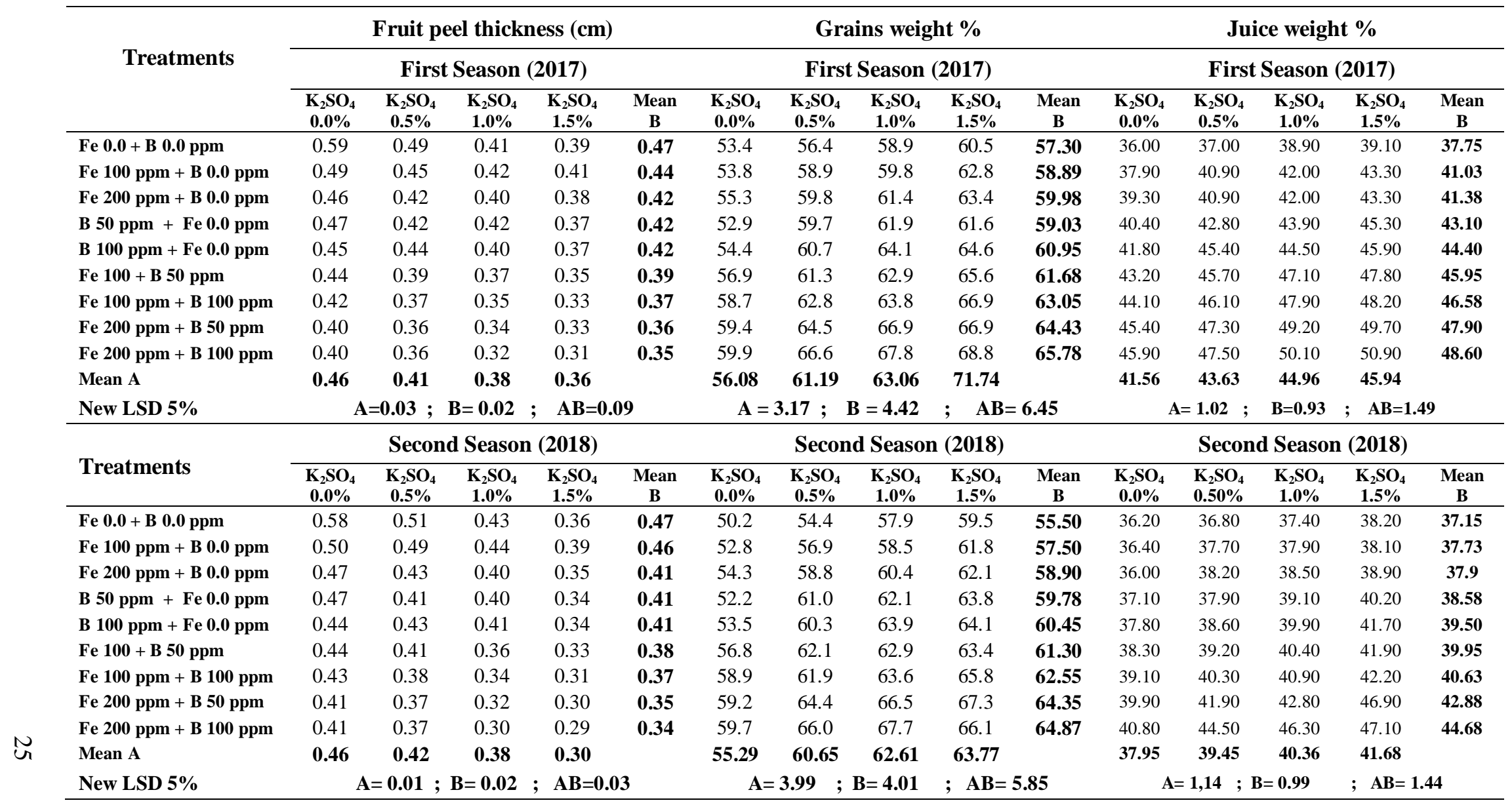




\section{Fruit cracked and fruit sunburned percentages}

It is well known that, pomegranate losses due to fruit cracking and fruit sunburn are quite high. Fruit cracking problem was due to improper water management and deficiency of some mineral nutrients. Furthermore, fruit cracked and fruit sunburned percentages are two of the most important factors limiting marketable value of pomegranate fruits. These two studied characters (Table, 4) were significantly reduced as a result of treating the trees with the three examined compounds $\left(\mathrm{K}_{2} \mathrm{SO}_{4}, \mathrm{FeSO}_{4}\right.$ and $\mathrm{H}_{3} \mathrm{BO}_{3}$ ). Spraying of $\mathrm{K}_{2} \mathrm{SO}_{4}$ at $1.5 \%$ recorded lowest value of fruit cracked (9.78 and $7.97 \%)$ and fruit sunburned $(8.58$ and $8.66 \%)$ in the two seasons respectively. Such reduction of both seasons was generally parallel to the gradual increase in potassium sulphate concentration, with the highest values being produced due to sprayed the trees by water, control treatment, (19.6 and $18.2 \%$ for fruit cracked percentage and 19.9 and $22.2 \%$ for fruit sunburned percentage), during the two seasons respectively. The lowest cracked fruit (7.9 and 5.0 $\%)$ and sunburned fruit (7.1 and 6.6\%) were obtained from interaction with to spraying potassium sulphate at $1.5 \%$ plus ferrous sulphate at $200 \mathrm{ppm}$ and boric acid at $100 \mathrm{ppm}$ together, during the two seasons respectively.

The improving effect of the three examined compounds on fruit physical properties might be attributed to its effect on enhancing plant pigments formation, building carbohydrates and activating the uptake of mineral nutrition and different enzymes activations, in addition to the role of potassium in plant tolerance of biotic and abiotic stress. Also, it is well known that $\mathrm{K}$ has a many functions in plant nutrition and growth that influence both yield and fruit quality. These included regulation of metabolic processes such as photosynthesis; activation of enzymes that metabolized carbohydrate for synthesis of amino acids and proteins; function of cell division and growth by helping to move starches and sugars between plant parts. The aforementioned roles of potassium could be explanted its effect on improve fruit weight and increasing the yield/tree and improving physical properties of fruit (Mengl (1985); Marschner (1997); Havlin et al., (2005); Khalil and Aly (2013); Kow and Nabwami (2015) and Abo-Ali (2019).

Boron is much required for cell division and development in the growth region of the plant. It also affects auxin synthesis, sugar transport and appears to be associated with some of functions of calcium (Sumam et al., 2017). These functions mentioned above of boron could be explained the remarkable effect of boric acid on enhancing fruit weight, total yield/tree as well as physical properties of fruit. Furthermore as an essential microelement,
Fe has important roles in plant growth such as acting as a cofactor of about 140 enzymes and being involved in synthesis of chlorophyll, thylakoid and chloroplast development (Marschner, 1997 \& Mengle, 2007).

The obtained results concerning the effect of $\mathrm{K}$, $\mathrm{Fe}$ and $\mathrm{B}$ on fruit physical properties, yield/tree as well as fruit weight are in accordance with those obtained on pomegranate trees and other fruit species by Arona and Singh (1970); Bambalet al. (1991); Alilaet al. (2004); Meenaet al. (2014); Davarpanahet al. (2013 \& 2016); El-Kady (2011); Khalil and Ali (2013); Abou El-Wafa (2015); Omar (2015); Kow and Nabwami (2015); Sumamet al. (2017) and Abo-Ali (2019).

\section{Fruit chemical properties}

\section{TSS \%, reducing and non-reducing sugars (\%)}

It is clear from the obtained data in Table (5) that spraying trees to single and combined applications of $\mathrm{K}_{2} \mathrm{SO}_{4}, \quad \mathrm{FeSO}_{4}$ and $\mathrm{H}_{3} \mathrm{BO}_{3}$ significantly enhanced the TSS\%, reducing sugars $\%$ and non-reducing sugars $\%$ compared to the control treatment. Spraying $\mathrm{K}_{2} \mathrm{SO}_{4}$ at the high concentration (1.5\%) was significantly favorable on TSS\% (15.69 and $15.81 \%)$, reducing sugars $\%$ (11.40 and $12.0 \%)$ and non-reducing sugars $\%(1.67$ and $1.71 \%)$ than using $\mathrm{K}_{2} \mathrm{SO}_{4}$ at lower concentrations (15.03 \& $15.08 \%$ for the TSS, 10.91 and $11.39 \%$ for reducing sugars and 1,56 and $1.50 \%$ for non-reducing sugars)during the two seasons respectively. The promotion on such these characteristics was significantly related to mixing $\mathrm{K}_{2} \mathrm{SO}_{4}$ with $\mathrm{FeSO}_{4}$ and $\mathrm{H}_{3} \mathrm{BO}_{3}$. Using $\mathrm{K}_{2} \mathrm{SO}_{4}$ in combined with $\mathrm{H}_{3} \mathrm{BO}_{3}$ was significantly superior than using each compound alone. Regardless the concentration used, the combined application of $\mathrm{FeSO}_{4}$ and $\mathrm{H}_{3} \mathrm{BO}_{3}$ in exhibited more effective, on the three studied characters, than sprayed each compound alone. It is worth to mentioned that data presented in same Table that the trees received $\mathrm{H}_{3} \mathrm{BO}_{3}$ alone or combined with $\mathrm{K}_{2} \mathrm{SO}_{4}$ produce more pronounced effect on TSS\%, reducing and non-reducing sugars than those received $\mathrm{FeSO}_{4}$ alone or combined with $\mathrm{K}_{2} \mathrm{SO}_{4}$ during the two experimental seasons.

The interactions between the three examined compounds on $\mathrm{TSS} \%$, reducing sugars $\%$ and nonreducing sugars $\%$ were significant. Furthermore, the highest T.S.S.\% (16.7 and 16.9\%), reducing sugars $(12.8$ and $13.0 \%)$ and non-reducing sugars (1.87 and $1.89 \%$ ) were produced from the fruit of the trees received potassium sulphate at $1.5 \%$ accompanied with $\mathrm{FeSO}_{4}$ at 200 ppm and $\mathrm{H}_{3} \mathrm{BO}_{3}$ at $100 \mathrm{ppm}$ in the two experimental seasons respectively. While, the least values of TSS \% (13.8 and 14.1\%) and reducing (10.0 and $10.8 \%)$ non-reducing sugars (1.11 and $1.01 \%$ ) were produced by untreated trees in the two seasons respectively. 
The promotion effect of $\mathrm{K}, \mathrm{Fe}$ and $\mathrm{B}$ on Wonderful pomegranate fruits that showed in the present investigation and noted by some local and strangers authors on pomegranate or other fruit trees (Singh et al., 2005 on papaya trees, Singh and Maurya (2004) on Mango trees and Sharma et al., 2005 on Litchi trees). The important roles of potassium concerning increasing total soluble solids and sugars in Wonderful pomegranate fruit can be explained by its effect on enzyme activation, cellular membrane transport processes and translocation of assimilates, anion neutralization, which is essential in maintenance of membrane potential and osmotic potential regulation, which is one of the important mechanisms in the control of plant water relations.
The promotion effect of potassium on Wonderful pomegranate fruits total soluble solids, reducing sugars and non-reducing sugars was reported by certain authors such as Mpelasoka et al., (2003); Zhang and Whiting (2011); Khalil and Ali (2013); Omar (2014); Wassel et al., (2015) on some pomegranate cultivars.Furthermore, boron can plays an important role in plant metabolism including many physiological aspects such as building and translocation of carbohydrates, photosynthesis, membrane function and water uptake. The roles can enhancing TSS and sugar contents in fruit juice (Marschner 1997; Babu and Yadav, 2005; Babu et al., 2007; Lalet et al., 2011; Mehta 2012; Messaoudi et al., 2012; and Khalil and Aly 2013).

Table 4. Effect of spraying potassium sulphate, ferrous sulphate, and boric acid on fruit cracked \% and fruit sunburned \% of Wonderful pomegranate trees during 2017 and 2018 seasons

\begin{tabular}{|c|c|c|c|c|c|c|c|c|c|c|}
\hline \multirow{3}{*}{ Treatments } & \multicolumn{5}{|c|}{ Cracked fruits (\%) } & \multicolumn{5}{|c|}{ Sunburned fruits (\%) } \\
\hline & \multicolumn{5}{|c|}{ First Season (2017) } & \multicolumn{5}{|c|}{ First Season (2017) } \\
\hline & $\begin{array}{c}\mathrm{K}_{2} \mathrm{SO}_{4} \\
\mathbf{0 . 0} \% \\
\end{array}$ & $\begin{array}{c}\mathrm{K}_{2} \mathrm{SO}_{4} \\
0.5 \%\end{array}$ & $\begin{array}{c}\mathrm{K}_{2} \mathrm{SO}_{4} \\
1.0 \% \\
\end{array}$ & $\begin{array}{c}\mathrm{K}_{2} \mathrm{SO}_{4} \\
1.5 \% \\
\end{array}$ & $\begin{array}{c}\text { Mean } \\
\text { B } \\
\end{array}$ & $\begin{array}{c}\mathrm{K}_{2} \mathrm{SO}_{4} \\
\mathbf{0 . 0 \%}\end{array}$ & $\begin{array}{c}\mathrm{K}_{2} \mathrm{SO}_{4} \\
0.5 \%\end{array}$ & $\begin{array}{c}\mathrm{K}_{2} \mathrm{SO}_{4} \\
1.0 \% \\
\end{array}$ & $\begin{array}{c}\mathrm{K}_{2} \mathrm{SO}_{4} \\
1.5 \% \\
\end{array}$ & $\begin{array}{c}\text { Mean } \\
\text { B }\end{array}$ \\
\hline Fe $0.0+$ B 0.0 ppm & 19.6 & 15.4 & 13.5 & 12.2 & 15.18 & 19.9 & 13.1 & 11.7 & 11.9 & 13.85 \\
\hline Fe 100 ppm + B 0.0 ppm & 13.5 & 10.8 & 12.4 & 11.7 & 12.10 & 15.4 & 12.5 & 10.9 & 9.1 & 11.97 \\
\hline Fe 200 ppm + B 0.0 ppm & 13.1 & 10.2 & 11.2 & 10.3 & 11.20 & 15.8 & 11.6 & 10.1 & 8.8 & 11.58 \\
\hline B 50 ppm + Fe 0.0 ppm & 14.3 & 11.1 & 12.4 & 10.2 & 12.00 & 14.1 & 12.4 & 10.7 & 9.5 & 11.23 \\
\hline B 100 ppm + Fe 0.0 ppm & 13.7 & 11.2 & 9.4 & 8.8 & 10.78 & 13.4 & 12.3 & 10.1 & 9.1 & 11.22 \\
\hline Fe 100 + B 50 ppm & 12.5 & 10.7 & 8.9 & 8.9 & 10.25 & 13.1 & 11.8 & 9.9 & 8.6 & 10.85 \\
\hline Fe 100 ppm + B 100 ppm & 12.0 & 12.1 & 9.0 & 9.9 & 10.75 & 12.1 & 10.8 & 9.6 & 7.7 & 10.05 \\
\hline Fe 200 ppm + B 50 ppm & 11.1 & 9.9 & 7.6 & 8.1 & 9.18 & 11.7 & 9.9 & 8.5 & 7.4 & 9.38 \\
\hline Fe 200 ppm + B 100 ppm & 9.8 & 9.2 & 7.0 & 7.9 & 8.13 & 11.2 & 9.7 & 8.1 & 7.1 & 9.03 \\
\hline Mean A & 12.68 & 11.82 & 10.16 & 9.78 & & 14.08 & 11.48 & 10.91 & 8.58 & \\
\hline New LSD $5 \%$ & \multicolumn{2}{|c|}{$\mathrm{A}=\mathbf{2 . 0 3}$} & $\mathrm{B}=3.34 ;$ & $\mathrm{AB}=4$ & & \multicolumn{2}{|c|}{$A=1.78$} & $=2.04$ & $\mathbf{A B}=\mathbf{2}$ & \\
\hline \multirow{2}{*}{ Treatments } & \multicolumn{5}{|c|}{ Second Season (2018) } & \multicolumn{5}{|c|}{ Second Season (2018) } \\
\hline & $\begin{array}{c}\mathrm{K}_{2} \mathrm{SO}_{4} \\
\mathbf{0 . 0} \%\end{array}$ & $\begin{array}{c}\mathrm{K}_{2} \mathrm{SO}_{4} \\
0.5 \%\end{array}$ & $\begin{array}{c}\mathrm{K}_{2} \mathrm{SO}_{4} \\
1.0 \%\end{array}$ & $\begin{array}{c}\mathrm{K}_{2} \mathrm{SO}_{4} \\
1.5 \%\end{array}$ & $\begin{array}{c}\text { Mean } \\
\text { B }\end{array}$ & $\begin{array}{c}\mathrm{K}_{2} \mathrm{SO}_{4} \\
0.0 \%\end{array}$ & $\begin{array}{c}\mathrm{K}_{2} \mathrm{SO}_{4} \\
0.5 \%\end{array}$ & $\begin{array}{c}\mathrm{K}_{2} \mathrm{SO}_{4} \\
1.0 \%\end{array}$ & $\begin{array}{c}\mathrm{K}_{2} \mathrm{SO}_{4} \\
1.5 \%\end{array}$ & $\begin{array}{c}\text { Mean } \\
\text { B }\end{array}$ \\
\hline Fe 0.0 + B 0.0 ppm & 18.2 & 13.1 & 12.4 & 11.6 & 13.83 & 22.2 & 17.1 & 13.7 & 10.9 & 15.97 \\
\hline Fe 100 ppm + B 0.0 ppm & 13.8 & 12.1 & 10.1 & 9.2 & 11.30 & 19.4 & 14.5 & 11.9 & 9.9 & 13.89 \\
\hline Fe 200 ppm + B 0.0 ppm & 11.6 & 9.2 & 8.8 & 7.6 & 9.30 & 17.8 & 13.6 & 11.1 & 9.0 & 12.88 \\
\hline B $50 \mathrm{ppm}+$ Fe $0.0 \mathrm{ppm}$ & 12.2 & 9.9 & 10.3 & 8.8 & 10.30 & 16.2 & 14.3 & 11.7 & 10.5 & 13.18 \\
\hline B 100 ppm + Fe 0.0 ppm & 10.4 & 9.2 & 9.5 & 8.6 & 9.43 & 13.7 & 12.1 & 10.3 & 9.2 & 11.33 \\
\hline Fe 100 + B 50 ppm & 10.2 & 8.5 & 8.2 & 8.1 & 8.75 & 12.1 & 11.5 & 9.2 & 8.0 & 10.2 \\
\hline Fe 100 ppm + B 100 ppm & 9.8 & 8.1 & 7.8 & 6.7 & 8.10 & 11.1 & 9.8 & 9.0 & 7.1 & 9.25 \\
\hline Fe 200 ppm + B 50 ppm & 8.9 & 7.0 & 6.9 & 6.1 & 7.23 & 10.8 & 8.8 & 8.0 & 6.8 & 8.62 \\
\hline Fe 200 ppm + B 100 ppm & 8.1 & 6.2 & 5.7 & 5.0 & 6.25 & 10.2 & 9.1 & 7.9 & 6.6 & 8.45 \\
\hline Mean A & 11.47 & 9.30 & 8.29 & 7.97 & & 15.01 & 12.31 & 10.60 & 8.66 & \\
\hline New LSD $5 \%$ & \multicolumn{2}{|c|}{$A=1.98$} & $B=2.41$ & $; \mathbf{A B}=$ & & \multicolumn{5}{|c|}{$A=2.18 ; B=2.55 ; A B=3.72$} \\
\hline
\end{tabular}

Total acidity percentage

Concerning the $\mathrm{K}_{2} \mathrm{SO}_{4} \quad \mathrm{FeSO}_{4} \quad$ or/and $\mathrm{H}_{3} \mathrm{BO}_{3}$ were capable of causing significant decrement in total acidity $\%$ in fruit juice of Wonderful pomegranate over the control trees during the two experimental seasons (Table 6). Total acidity was gradually decreased during the two seasons parallel to the gradual increase in $\mathrm{K}_{2} \mathrm{SO}_{4}$ and $\mathrm{FeSO}_{4}$ or/and $\mathrm{H}_{3} \mathrm{BO}_{3}$ concentrations. Spraying trees three times of different concentration of $\mathrm{FeSO}_{4}$ or/and $\mathrm{H}_{3} \mathrm{BO}_{3}$ significantly was responsible for decreasing the percentage total acidity $\%$ rather than untreated trees. There was a remarkable diminishing on total acidity $\%$ with increasing concentrations of $\mathrm{FeSO}_{4}$ from 100 to $200 \mathrm{ppm}$ or/and $\mathrm{H}_{3} \mathrm{BO}_{3}$ from 50 to $100 \mathrm{ppm}$. However, regardless the concentration use, the combined application of $\mathrm{FeSO}_{4}$ and $\mathrm{H}_{3} \mathrm{BO}_{3}$ exhibited more effective on total acidity $\%$ than sprayed each one alone. 
Regarding the interactions between the three examined compounds, increasing $\mathrm{K}_{2} \mathrm{SO}_{4}$ concentration companied with $\mathrm{FeSO}_{4}$ or/and $\mathrm{H}_{3} \mathrm{BO}_{3}$ significantly decreased total acidity \% during the two experimental season. Furthermore, the lowest total acidity \% (1.320 and $1.339 \%)$ were obtained from the trees received $\mathrm{K}_{2} \mathrm{SO}_{4}$ at $1.5 \%$ companied with $\mathrm{FeSO}_{4}$ at $200 \mathrm{ppm}$ and $\mathrm{H}_{3} \mathrm{BO}_{3}$ at $100 \mathrm{ppm}$ in the two experimental seasons respectively. On the other hand, the maximum total acidity $\%$ (1.712 and $1.701 \%)$, during the two experimental seasons respectively, were produced by untreated trees.

Furthermore, it worth to mentioned that, regardless the concentration used the treatments included $\mathrm{K}_{2} \mathrm{SO}_{4}$ combined with $\mathrm{H}_{3} \mathrm{BO}_{3}$ were remarkable more effective on the total acidity decrement than those of $\mathrm{K}_{2} \mathrm{SO}_{4}$ combined plus $\mathrm{FeSO}_{4}$.

The role of spraying potassium sulphate in increasing the total acidity \% was illustrated by Omar, (2015); Abd-El-Rhman et al., (2017); Davarpanh et al., (2017); Ampem (2017) and Abo-Ali (2019) on different cultivars of pomegranate.

\section{Fruit peel and juice total anthocyanin contents}

Data in Table (6) show that the fruit peel and juice total anthocyanin contents (mg/100 g F.W.) in fruit treated with different compounds or the concentrations were significant differences observed in peel and juice total anthocyanin contents during the two seasons. Gradual and significant increment in both peel and juice anthocyanin contents was observed as a result of increasing $\mathrm{K}_{2} \mathrm{SO}_{4}$ concentration from 0.0 to $1.5 \%$, rather than control treatment. Regarding the concentration used, trees treated with potassium sulphate at $1.5 \%$ produced highest peel and juice anthocyanin pigments ( 84 and $85 \mathrm{mg} / 100 \mathrm{~g} \mathrm{~F} . \mathrm{W}$. and 109 and $116 \mathrm{mg} / 100 \mathrm{~g} \mathrm{~F}$.W. in the two seasons respectively) rather than those treated with other potassium sulphate concentrations. While, increasing potassium sulphate from $1.0 \%$ to $1.5 \%$ failed to enhanced peel and juice anthocyanin pigments significantly. On the other hand, untreated trees produced the lowest anthocyanin contents in fruit peel (55 and $51 \mathrm{mg} / 100$ g F.W.) and juice (73 and $79 \mathrm{mg} / 100 \mathrm{~g} \mathrm{~F}$. W.) during the two experimental seasons respectively.

All treatments concerning added $\mathrm{FeSO}_{4}$ or/and $\mathrm{H}_{3} \mathrm{BO}_{3}$ each alone or in companied caused a significant increase in peel and juice anthocyanin contents during the two seasons, except those of spraying the lowest $\mathrm{FeSO}_{4}$ concentration (100 ppm) alone or in combined with potassium sulphate, during the two seasons. Furthermore, it is clear also from the same Tables that the combined treatments of $\mathrm{FeSO}_{4}$ and $\mathrm{H}_{3} \mathrm{BO}_{3}$ lead to enhance of fruit peel and juice anthocyanin contents than those produced by the trees treated with each compound alone. The interaction between $\mathrm{K}_{2} \mathrm{SO}_{4}, \mathrm{FeSO}_{4}$ and $\mathrm{H}_{3} \mathrm{BO}_{3}$ was significant in the two experimental seasons. It was clear that Fe-sulphate at $100 \& 200 \mathrm{ppm}$ and boric acid at $50 \& 100 \mathrm{ppm}$ accompanied with potassium sulphate at $0.5 \%$ to $1.5 \%$ higher present and significant peel and juice anthocyanin contents rather than untreated trees. However the highest peel ( 84 and $85 \mathrm{mg} / 100$ g F.W.) and juice (109 and 116 $\mathrm{mg} / 100 \mathrm{~g}$ F.W.) anthocyanin contents were produced from the trees received a mixture of $\mathrm{K}_{2} \mathrm{SO}_{4}$ at $1 \%+\mathrm{FeSO}_{4}$ at $200 \mathrm{ppm}+\mathrm{H}_{3} \mathrm{BO}_{3}$ at $100 \mathrm{ppm}$. On the other hand, untreated trees produced the lowest anthocyanin contents in peel $(55 \& 51 \mathrm{mg} / 100 \mathrm{~g}$ F.W.) and juice (73 and $79 \mathrm{mg} / 100 \mathrm{~g} \mathrm{~F} . \mathrm{W})$ during the two seasons respectively.

The increase in total anthocyanin contents because of spraying potassium sulphate are in line with the findings of Tehranifar and Tabar (2009) and Moor et al., (2009). A positive correlation between $\mathrm{K}$ concentration and anthocyanin contents, and also the importance of balance between the concentration of $\mathrm{N}$ and $\mathrm{K}$ on total anthocyanin contents have been reported. For instance, unbalanced nutrition or excessive nutrition of $\mathrm{N}$ and $\mathrm{K}$ lead to decrease the contents of total anthocyanin in grape (Hunsche et al., 2003; Delgado et al., 2006). It is worth to mention that potassium plays crucial roles in anthocyanin's synthesis through increasing the translocation of sugars into fruits, as well as acting as a cofactor and stimulator of some enzymes like UDP-galactose: flavanoide-3-o-glicosil transferase (Ju et al., 1999 and Delgado et al., 2006).

There is a wide variety of reported beneficial effects of single or combined spraying of potassium, iron and boron on the chemical properties of Wonderful pomegranate or other pomegranate cultivars fruit, like increasing juice weight $\%$ and TSS\% Kahayyat et al., (2012) and Sheikh and Manjula (2012); (Hamouda et al., (2015) on Manfalouty pomegranate $c v$; Salama et al. (2016) on Wonderful pomegranate. Increasing TSS\% and decreasing total acidity \% (Abd-El-Rhman et al. (2017) on Manfalouty pomegranate; Parvin et al. (2017) on Kandhari pomegranate cv.; Davarpanah et al., 2017, on Malas-e-Saveh pomegranate cv., increasing juice fruit reducing and non-reducing sugars\% Sharma and Belsare (2011); Abo ElWafa (2015) on Wondeful pomegranate; Davarpanah et al. (2017) on Malas-e-Saveh pomegranate cv. and Abo-Ali (2019) on Wonderful pomegranate and Ampem (2017) on three South African commercial pomegranate cultivars namely: Wonderful, Acco and Herskovitz. It is worth to mention that, their obtained results are in agreement with or findings during present investigation. 
Table 5. Effect of spraying potassium sulphate, ferrous sulphate, and boric acid on TSS, reducing and non-reducing sugars percentages of Wonderful pomegranate juice during 2017 and 2018 seasons

\begin{tabular}{|c|c|c|c|c|c|c|c|c|c|c|c|c|c|c|c|}
\hline \multirow{3}{*}{ Treatments } & \multicolumn{5}{|c|}{ TSS \% } & \multicolumn{5}{|c|}{ Reducing sugars \% } & \multicolumn{5}{|c|}{ Non-reducing sugars \% } \\
\hline & \multicolumn{5}{|c|}{ First season (2017) } & \multicolumn{5}{|c|}{ First season (2017) } & \multicolumn{5}{|c|}{ First season (2017) } \\
\hline & $\begin{array}{c}\mathrm{K}_{2} \mathrm{SO}_{4} \\
0.0 \%\end{array}$ & $\begin{array}{l}\mathrm{K}_{2} \mathrm{SO}_{4} \\
\mathbf{0 . 5 0 \%} \\
\end{array}$ & $\begin{array}{c}\mathrm{K}_{2} \mathrm{SO}_{4} \\
1.0 \%\end{array}$ & $\begin{array}{c}\mathrm{K}_{2} \mathrm{SO}_{4} \\
1.5 \% \\
\end{array}$ & $\begin{array}{c}\text { Mean } \\
\text { B }\end{array}$ & $\begin{array}{c}\mathrm{K}_{2} \mathrm{SO}_{4} \\
\mathbf{0 . 0 \%}\end{array}$ & $\begin{array}{l}\mathrm{K}_{2} \mathbf{S O}_{4} \\
\mathbf{0 . 5 0 \%} \\
\end{array}$ & $\begin{array}{c}\mathrm{K}_{2} \mathrm{SO}_{4} \\
1.0 \% \\
\end{array}$ & $\begin{array}{c}\mathrm{K}_{2} \mathrm{SO}_{4} \\
1.5 \% \\
\end{array}$ & $\begin{array}{c}\text { Mean } \\
\text { B }\end{array}$ & $\begin{array}{c}\mathrm{K}_{2} \mathbf{S O}_{4} \\
\mathbf{0 . 0 \%} \\
\end{array}$ & $\begin{array}{l}\mathrm{K}_{2} \mathrm{SO}_{4} \\
\mathbf{0 . 5 0 \%} \\
\end{array}$ & $\begin{array}{c}\mathrm{K}_{2} \mathrm{SO}_{4} \\
1.0 \% \\
\end{array}$ & $\begin{array}{c}\mathrm{K}_{2} \mathrm{SO}_{4} \\
1.5 \% \\
\end{array}$ & $\begin{array}{c}\text { Mean } \\
\text { B }\end{array}$ \\
\hline Fe $0.0+B$ B 0.0 ppm & 13.80 & 14.20 & 14.60 & 14.80 & 14.35 & 10.00 & 10.10 & 10.30 & 10.40 & 10.20 & 1.11 & 1.19 & 1.29 & 1.33 & 1.23 \\
\hline Fe 100 ppm + B 0.0 ppm & 14.10 & 14.60 & 14.80 & 14.90 & 14.60 & 10.20 & 10.40 & 10.40 & 10.60 & 10.40 & 1.19 & 1.23 & 1.33 & 1.39 & 1.29 \\
\hline Fe 200 ppm + B 0.0 ppm & 14.40 & 14.90 & 15.30 & 15.40 & 15.00 & 10.40 & 10.50 & 10.70 & 10.80 & 10.60 & 1.21 & 1.39 & 1.42 & 1.54 & 1.39 \\
\hline B 50 ppm + Fe 0.0 ppm & 14.60 & 14.90 & 15.20 & 15.20 & 14.98 & 10.50 & 10.80 & 10.90 & 11.10 & 10.83 & 1.37 & 1.55 & 1.59 & 1.66 & 1.54 \\
\hline B 100 ppm + Fe 0.0 ppm & 15.00 & 15.10 & 15.50 & 15.70 & 15.33 & 10.70 & 10.90 & 11.20 & 11.40 & 11.05 & 1.47 & 1.65 & 1.69 & 1.78 & 1.65 \\
\hline Fe $100+B 50$ ppm & 15.30 & 15.40 & 15.60 & 15.80 & 15.53 & 10.8 & 10.90 & 11.60 & 11.70 & 11.25 & 1.55 & 1.69 & 1.75 & 1.79 & 1.70 \\
\hline Fe 100 ppm + B 100 ppm & 15.80 & 15.90 & 16.00 & 16.30 & 16.00 & 10.90 & 11.30 & 11.50 & 11.90 & 11.40 & 1.66 & 1.77 & 1.79 & 1.80 & 1.76 \\
\hline Fe 200 ppm + B 50 ppm & 16.00 & 16.20 & 16.40 & 16.40 & 16.25 & 11.40 & 11.50 & 11.70 & 11.90 & 11.63 & 1.69 & 1.79 & 1.81 & 1.85 & 1.79 \\
\hline Fe $200 \mathrm{ppm}+\mathrm{B} 100 \mathrm{ppm}$ & 16.20 & 16.40 & 16.60 & 16.70 & 16.48 & 11.70 & 11.90 & 12.40 & 12.80 & 12.20 & 1.73 & 1.80 & 1.84 & 1.87 & 1.81 \\
\hline Mean A & 15.03 & 15.29 & 15.56 & 15.69 & & 10.73 & 10.91 & 11.19 & 11.40 & & 1.44 & 1.56 & 1.61 & 1.67 & \\
\hline New LSD 5\% & \multicolumn{2}{|c|}{$A=0.15$} & $B=0.08$ & \multicolumn{2}{|c|}{; $\quad \mathrm{AB}=\mathbf{0 . 1 2}$} & \multicolumn{2}{|c|}{$A=0.19$} & $\mathrm{~B}=\mathbf{0 . 2 3}$ & \multicolumn{2}{|c|}{; $\mathrm{AB}=\mathbf{0 . 3 4}$} & \multicolumn{2}{|c|}{$\mathrm{A}=\mathbf{0 . 2 0}$} & $B=0.12$ & $\mathrm{AB}=0$ & \\
\hline \multirow{2}{*}{ Treatments } & \multicolumn{5}{|c|}{ Second season $(2018)$} & \multicolumn{5}{|c|}{ Second season $(2018)$} & \multicolumn{5}{|c|}{ Second season (2018) } \\
\hline & $\begin{array}{c}\mathrm{K}_{2} \mathrm{SO}_{4} \\
0.0 \% \\
\end{array}$ & $\begin{array}{l}\mathrm{K}_{2} \mathbf{S O}_{4} \\
\mathbf{0 . 5 0 \%} \\
\end{array}$ & $\begin{array}{c}\mathrm{K}_{2} \mathrm{SO}_{4} \\
1.0 \%\end{array}$ & $\begin{array}{c}\mathrm{K}_{2} \mathrm{SO}_{4} \\
1.5 \% \\
\end{array}$ & $\begin{array}{c}\text { Mean } \\
\text { B }\end{array}$ & $\begin{array}{c}\mathbf{K}_{2} \mathbf{S O}_{4} \\
\mathbf{0 . 0 \%}\end{array}$ & $\begin{array}{l}\mathbf{K}_{2} \mathbf{S O}_{4} \\
\mathbf{0 . 5 0 \%} \\
\end{array}$ & $\begin{array}{c}\mathrm{K}_{2} \mathrm{SO}_{4} \\
1.0 \%\end{array}$ & $\begin{array}{c}\mathrm{K}_{2} \mathrm{SO}_{4} \\
1.5 \%\end{array}$ & $\begin{array}{c}\text { Mean } \\
\text { B }\end{array}$ & $\begin{array}{c}\mathrm{K}_{2} \mathbf{S O}_{4} \\
\mathbf{0 . 0 \%} \\
\end{array}$ & $\begin{array}{l}\mathrm{K}_{2} \mathbf{S O}_{4} \\
\mathbf{0 . 5 0 \%} \\
\end{array}$ & $\begin{array}{c}\mathrm{K}_{2} \mathrm{SO}_{4} \\
1.0 \%\end{array}$ & $\begin{array}{c}\mathrm{K}_{2} \mathrm{SO}_{4} \\
1.5 \% \\
\end{array}$ & $\begin{array}{c}\text { Mean } \\
\text { B }\end{array}$ \\
\hline Fe $0.0+B$ B 0.0 ppm & 14.10 & 14.20 & 14.50 & 14.80 & 14.40 & 10.20 & 10.50 & 10.70 & 10.80 & 10.55 & 1.01 & 1.21 & 1.31 & 1.44 & 1.24 \\
\hline Fe 100 ppm + B 0.0 ppm & 14.30 & 14.40 & 14.80 & 14.90 & 14.60 & 10.40 & 10.60 & 10.90 & 11.30 & 10.80 & 1.11 & 1.33 & 1.43 & 1.51 & 1.35 \\
\hline Fe 200 ppm + B 0.0 ppm & 14.60 & 14.90 & 15.00 & 15.20 & 14.93 & 10.70 & 10.80 & 10.90 & 11.60 & 11.00 & 1.17 & 1.39 & 1.41 & 1.66 & 1.41 \\
\hline B $50 \mathrm{ppm}+$ Fe $0.0 \mathrm{ppm}$ & 14.90 & 15.20 & 15.40 & 15.50 & 15.25 & 10.80 & 10.90 & 11.30 & 11.70 & 11.18 & 1.23 & 1.41 & 1.53 & 1.69 & 1.47 \\
\hline B $100 \mathrm{ppm}+\mathrm{Fe} 0.0 \mathrm{ppm}$ & 15.00 & 15.30 & 15.70 & 15.70 & 15.43 & 10.90 & 11.50 & 11.90 & 12.10 & 11.60 & 1.33 & 1.49 & 1.66 & 1.73 & 1.56 \\
\hline Fe $100+B 50$ ppm & 15.20 & 15.50 & 15.90 & 16.10 & 15.68 & 11.10 & 11.60 & 11.90 & 12.40 & 11.75 & 1.39 & 1.51 & 1.71 & 1.77 & 1.60 \\
\hline Fe 100 ppm + B 100 ppm & 15.70 & 15.90 & 16.30 & 16.50 & 16.10 & 11.30 & 11.90 & 12.20 & 12.50 & 11.98 & 1.51 & 1.67 & 1.73 & 1.81 & 1.68 \\
\hline Fe 200 ppm + B 50 ppm & 15.90 & 16.00 & 16.40 & 16.70 & 16.25 & 11.90 & 12.10 & 12.40 & 12.60 & 12.25 & 1.55 & 1.71 & 1.80 & 1.85 & 1.73 \\
\hline Fe $200 \mathrm{ppm}+\mathrm{B} 100 \mathrm{ppm}$ & 16.00 & 16.20 & 16.50 & 16.90 & 16.4 & 12.00 & 12.60 & 12.70 & 13.00 & 12.58 & 1.67 & 1.75 & 1.84 & 1.89 & 1.79 \\
\hline Mean A & 15.08 & 15.29 & 15.61 & 15.81 & & 11.03 & 11.39 & 11.65 & 12.00 & & 1.33 & 1.50 & 1.60 & 1.71 & \\
\hline New LSD 5\% & \multicolumn{2}{|c|}{$A=0.22$} & $\mathrm{~B}=0.22$ & ; $\quad \mathbf{A B}=\mathbf{0}$ & & \multicolumn{2}{|c|}{$A=0.28$} & $B=\mathbf{0 . 3 3}$ & \multicolumn{2}{|c|}{$\mathrm{AB}=0.48$} & \multicolumn{2}{|c|}{$\mathbf{A}=\mathbf{0 . 1 0}$} & $B=0.10$ & ; $\mathbf{A B}=\mathbf{0}$. & \\
\hline
\end{tabular}


Table 6. Effect of spraying potassium sulphate, ferrous sulphate, and boric acid on total acidity \%, peel and juice total anthocyanin (mg/100g F.w.) of Wonderful pomegranate fruits during 2017 and 2018 seasons

\begin{tabular}{|c|c|c|c|c|c|c|c|c|c|c|c|c|c|c|c|}
\hline \multirow{3}{*}{ Treatments } & \multicolumn{5}{|c|}{ Total acidity \% } & \multicolumn{5}{|c|}{ Peel anthocyanin (mg/100g F.W.) } & \multicolumn{5}{|c|}{ Juice anthocyanin (mg/100g F.W.) } \\
\hline & \multicolumn{5}{|c|}{ First season (2017) } & \multicolumn{5}{|c|}{ First season (2017) } & \multicolumn{5}{|c|}{ First season (2017) } \\
\hline & $\begin{array}{c}\mathrm{K}_{2} \mathrm{SO}_{4} \\
\mathbf{0 . 0 \%}\end{array}$ & $\begin{array}{c}\mathrm{K}_{2} \mathrm{SO}_{4} \\
0.5 \%\end{array}$ & $\begin{array}{c}\mathrm{K}_{2} \mathrm{SO}_{4} \\
1.0 \%\end{array}$ & $\begin{array}{c}\mathrm{K}_{2} \mathrm{SO}_{4} \\
1.5 \%\end{array}$ & $\begin{array}{c}\text { Mean } \\
\text { B }\end{array}$ & $\begin{array}{l}\mathrm{K}_{2} \mathrm{SO}_{4} \\
0.0 \%\end{array}$ & $\begin{array}{c}\mathrm{K}_{2} \mathrm{SO}_{4} \\
0.5 \%\end{array}$ & $\begin{array}{c}\mathrm{K}_{2} \mathrm{SO}_{4} \\
1.0 \%\end{array}$ & $\begin{array}{c}\mathrm{K}_{2} \mathrm{SO}_{4} \\
1.5 \%\end{array}$ & $\begin{array}{c}\text { Mean } \\
\text { B }\end{array}$ & $\begin{array}{l}\mathrm{K}_{2} \mathrm{SO}_{4} \\
0.0 \%\end{array}$ & $\begin{array}{c}\mathrm{K}_{2} \mathrm{SO}_{4} \\
\mathbf{0 . 5 \%}\end{array}$ & $\begin{array}{c}\mathrm{K}_{2} \mathrm{SO}_{4} \\
1.0 \%\end{array}$ & $\begin{array}{c}\mathrm{K}_{2} \mathrm{SO}_{4} \\
1.5 \%\end{array}$ & $\begin{array}{c}\text { Mean } \\
\text { B }\end{array}$ \\
\hline $\mathrm{Fe} 0.0+\mathrm{B} 0.0 \mathrm{ppm}$ & 1.712 & 1.711 & 1.682 & 1.651 & 1.691 & 55.00 & 61.00 & 66.00 & 68.00 & 62.50 & 73.00 & 79.00 & 80.00 & 82.00 & 78.50 \\
\hline Fe 100 ppm + B 0.0 ppm & 1.700 & 1.692 & 1.683 & 1.641 & 1.679 & 56.00 & 61.00 & 69.00 & 71.00 & 64.30 & 75.00 & 81.00 & 84.00 & 87.00 & 81.80 \\
\hline Fe 200 ppm + B 0.0 ppm & 1.688 & 1.641 & 1.625 & 1.603 & 1.639 & 58.00 & 62.00 & 71.00 & 72.00 & 65.80 & 76.00 & 81.00 & 87.00 & 96.00 & 85.00 \\
\hline B 50 ppm + Fe 0.0 ppm & 1.613 & 1.611 & 1.581 & 1.509 & 1.578 & 58.00 & 64.00 & 75.00 & 77.00 & 68.50 & 79.00 & 83.00 & 89.00 & 96.00 & 86.80 \\
\hline B $100 \mathrm{ppm}+\mathrm{Fe} 0.0 \mathrm{ppm}$ & 1.601 & 1.590 & 1.497 & 1.470 & 1.539 & 59.00 & 65.00 & 76.00 & 78.00 & 69.50 & 83.00 & 87.00 & 94.00 & 98.00 & 90.50 \\
\hline Fe $100+B 50$ ppm & 1.569 & 1.522 & 1.401 & 1.399 & 1.472 & 61.00 & 64.00 & 78.00 & 80.00 & 70.80 & 84.00 & 88.00 & 95.00 & 102.00 & 92.30 \\
\hline Fe 100 ppm + B 100 ppm & 1.531 & 1.502 & 1.391 & 1.372 & 1.449 & 62.00 & 66.00 & 80.00 & 82.00 & 72.50 & 86.00 & 90.00 & 93.00 & 104.00 & 93.30 \\
\hline Fe 200 ppm + B 50 ppm & 1.501 & 1.489 & 1.372 & 1.360 & 1.431 & 63.00 & 67.00 & 81.00 & 84.00 & $\mathbf{7 3 . 8 0}$ & 90.00 & 93.00 & 97.00 & 106.00 & 96.50 \\
\hline Fe 200 ppm + B 100 ppm & 1.471 & 1.422 & 1.351 & 1.320 & 1.391 & 65.00 & 71.00 & 82.00 & 84.00 & 75.50 & 92.00 & 96.00 & 101.00 & 109.00 & 99.50 \\
\hline Mean A & 1.599 & 1.573 & 1.509 & 1.481 & & 59.70 & 64.60 & 75.30 & 77.30 & & 81.57 & 86.40 & 91.10 & 97.80 & \\
\hline New LSD 5\% & \multicolumn{2}{|c|}{$A=0.026$} & $B=0.055$ & \multicolumn{2}{|c|}{$\mathrm{AB}=0.079$} & \multicolumn{2}{|c|}{$\mathrm{A}=\mathbf{3 . 6 3}$} & $B=2.11 ;$ & $\mathrm{AB}=3.08$ & & \multicolumn{2}{|c|}{$\mathrm{A}=4.32 \quad ;$} & $\mathrm{B}=\mathbf{3 . 5 0}$ & ; $\mathrm{AB}=4.35$ & \\
\hline \multirow[b]{2}{*}{ Treatments } & \multicolumn{5}{|c|}{ Second season (2018) } & \multicolumn{5}{|c|}{ Second season (2018) } & \multicolumn{5}{|c|}{ Second season (2018) } \\
\hline & $\begin{array}{c}\mathrm{K}_{2} \mathrm{SO}_{4} \\
\mathbf{0 . 0 \%}\end{array}$ & $\begin{array}{c}\mathrm{K}_{2} \mathrm{SO}_{4} \\
0.5 \%\end{array}$ & $\begin{array}{c}\mathrm{K}_{2} \mathrm{SO}_{4} \\
1.0 \%\end{array}$ & $\begin{array}{c}\mathrm{K}_{2} \mathrm{SO}_{4} \\
1.5 \%\end{array}$ & $\begin{array}{c}\text { Mean } \\
\text { B }\end{array}$ & $\begin{array}{c}\mathrm{K}_{2} \mathrm{SO}_{4} \\
0.0 \%\end{array}$ & $\begin{array}{c}\mathrm{K}_{2} \mathrm{SO}_{4} \\
\mathbf{0 . 5 \%}\end{array}$ & $\begin{array}{c}\mathrm{K}_{2} \mathrm{SO}_{4} \\
1.0 \%\end{array}$ & $\begin{array}{c}\mathrm{K}_{2} \mathrm{SO}_{4} \\
1.5 \% \\
\end{array}$ & $\begin{array}{c}\text { Mean } \\
\text { B }\end{array}$ & $\begin{array}{c}\mathrm{K}_{2} \mathrm{SO}_{4} \\
0.0 \%\end{array}$ & $\begin{array}{c}\mathrm{K}_{2} \mathrm{SO}_{4} \\
0.5 \%\end{array}$ & $\begin{array}{c}\mathrm{K}_{2} \mathrm{SO}_{4} \\
1.0 \%\end{array}$ & $\begin{array}{c}\mathrm{K}_{2} \mathrm{SO}_{4} \\
1.5 \%\end{array}$ & $\begin{array}{c}\text { Mean } \\
\text { B }\end{array}$ \\
\hline Fe 0.0 + B 0.0 ppm & 1.701 & 1.699 & 1.663 & 1.662 & 1.681 & 51.00 & 57.00 & 63.00 & 65.00 & 59.00 & 79.00 & 79.00 & 82.00 & 86.00 & 81.50 \\
\hline Fe 100 ppm + B 0.0 ppm & 1.691 & 1.684 & 1.678 & 1.659 & 1.678 & 52.00 & 59.00 & 64.00 & 68.00 & 60.80 & 80.00 & 82.00 & 87.00 & 89.00 & 84.50 \\
\hline Fe 200 ppm + B 0.0 ppm & 1.671 & 1.644 & 1.631 & 1.622 & 1.642 & 54.00 & 61.00 & 67.00 & 69.00 & 62.00 & 82.00 & 84.00 & 89.00 & 93.00 & 87.00 \\
\hline B $50 \mathrm{ppm}+\mathrm{Fe} 0.0 \mathrm{ppm}$ & 1.651 & 1.630 & 1.629 & 1.620 & 1.633 & 55.00 & 66.00 & 69.00 & 70.00 & 63.80 & 79.00 & 85.00 & 90.00 & 99.00 & 88.30 \\
\hline B $100 \mathrm{ppm}+\mathrm{Fe} 0.0 \mathrm{ppm}$ & 1.601 & 1.582 & 1.562 & 1.533 & 1.568 & 57.00 & 66.00 & 72.00 & 73.00 & 67.00 & 86.00 & 89.00 & 97.00 & 103.00 & 93.70 \\
\hline $\mathrm{Fe} 100+\mathrm{B} 50 \mathrm{ppm}$ & 1.599 & 1.581 & 1.571 & 1.566 & 1.577 & 59.00 & 67.00 & 75.00 & 77.00 & 69.50 & 88.00 & 93.00 & 97.00 & 106.00 & 96.00 \\
\hline Fe $100 \mathrm{ppm}+\mathrm{B} 100 \mathrm{ppm}$ & 1.512 & 1.501 & 1.488 & 1.438 & 1.485 & 62.00 & 69.00 & 78.00 & 80.00 & 71.50 & 91.00 & 95.00 & 99.00 & 109.00 & 98.50 \\
\hline Fe 200 ppm + B 50 ppm & 1.499 & 1.487 & 1.463 & 1.446 & 1.473 & 66.00 & 71.00 & 80.00 & 82.00 & 74.80 & 92.00 & 98.00 & 103.00 & 111.00 & $\begin{array}{c}101.0 \\
0\end{array}$ \\
\hline Fe 200 ppm + B 100 ppm & 1.488 & 1.467 & 1.410 & 1.339 & 1.421 & 67.00 & 73.00 & 83.00 & 85.00 & 77.00 & 93.00 & 102.00 & 105.00 & 116.00 & $\begin{array}{c}104.0 \\
0\end{array}$ \\
\hline Mean A & 1.602 & 1.586 & 1.566 & 1.531 & & $\mathbf{5 8 . 1 0}$ & 65.40 & 72.30 & 74.30 & & 85.60 & 89.70 & 94.30 & 101.30 & \\
\hline New LSD $5 \%$ & \multicolumn{2}{|c|}{$A=0.045$} & $B=0.034$ & \multicolumn{2}{|c|}{ ； $\mathrm{AB}=\mathbf{0 . 0 4 9}$} & \multicolumn{2}{|c|}{$\mathrm{A}=\mathbf{4 . 3 1}$} & $3=1.97$ & \multicolumn{2}{|c|}{; $\mathrm{AB}=\mathbf{2 . 8 7}$} & \multicolumn{2}{|c|}{$A=3.43$} & $B=3.82$ & $\mathrm{AB}=5.28$ & \\
\hline
\end{tabular}




\section{CONCLUSION}

In conclusion, for improve fruit physical and chemical properties of Wonderful pomegranate; it is necessary spraying the trees with potassium sulphate at $1.5 \%$, ferrous sulphate at $200 \mathrm{ppm}$ and boric acid at $100 \mathrm{ppm}$ three times on during growth cycle.

\section{REFERENCES}

Abd-El-Gabber, N.M. (2009). Response of Red Roomy grapevines to foliar application of boron, magnesium and Zinc. Ms.C. Hort. Dept. Fac. of Agric. Minia Univ.

Abd-El-Rhman, I.E.; Attia, F.M.; El-Hady, E.S. and Haggag, L.F. (2017). Effect of spraying of some antioxidants and micronutrients on yield, fruit quality and leaf mineral content of Manfalouty pomegranate trees (Punica granatum L.) grown in a calcareous soil. Middle East J. of Applied Sci., 7 (4): 713-725.

Abo-Ali, H.F.R. (2019). Physiological and histological studies on Wonderful pomegranate $c v$. M.Sc. Hort. Pomology, Fac. Agric. Azhar University.

Abou El-Wafa, M. (2015). Effect of some treatments on reducing sunburn in Wonderful pomegranate fruit trees. Egyptian J. Horticulture, 42 (42): 795-806.

Alila, P.; Sanyal, D. and Sema, K.A. (2004). Influence of micronutrient application on quality of papaya cv. Ranchi. Haryana J. Hort. Sci., 33 (1/2): 25-26.

Ampem, G. (2017). Quality attributes of pomegranate fruit and co-products relevant to processing and nutrition. M.Sc. Theses, Fac. of AgriScince. Stellembosch Univ. South Africa.

Arona, J.S. and Singh, J.R. (1970). Some effects of iron spray on growth, yield and quality of guava fruits (Psidium guajava L.). J. Japan Soc. Hort. Sci., 39 (2): 139-142.

A.O.A.C. (2006). Official Methods of Analysis of the Association of Official Agricultural Chemists. Seventeen edition, Washington, D. C., USA. pp $494-$ 510.

Babu, K.D.; Dubey, A.K. and Yadav, D.S. (2007). Effect of micronutrients on enhancing the productivity and quality of Kinnow Mandarin. Indian J. Hort., 64 (3): 353-356.

Babu, K.D. and Yadav, D.S. (2005). Foliar spray of micronutrients for yield and fruit quality improvement in Khasi mandarin (Citrus reticulate Blanco.). Indian J. Hort., 62 (2): 280-281.

Bambal, S.B.; Wavhal, K.N. and Nasalkak, S.D. (1991). Effect of foliar application of micronutrients on fruit quality and yield of pomegranate (Punica granatum L. cv Ganesh). J. Hort., 5 (2): 32-36.

Catola, S.; Marino, G.; Emiliani, G.; Huseynov, T. (2016). Physiological and metabolomics analysis of Punica granatum (L.) under drought stress. Planta, 243: 441-449.

Chaney, R.L., Brown, J.C. and Tiffin, L. O. (1972). Obligatory reduction of ferric chelates in iron uptake by soybeans. Plant Physiol., 50: 208213.

Davarpanah, S.; Aakari, M.A.; Babalar, M.;Zarei, M.; Aghayeh, R.N.M. (2017). Effect of foliar application of phosphorus, potassium and iron on physical and chemical properties of pomegranate fruit. Jordan J. Agric. Sci., 13 (3): 693-706.

Davarpanah, S.; Akbari, M.; Askari, M.A.; Nadda, M.E. (2013). Effect of iron foliar application (Fe-EDDHA) on quantitative and qualitative characteristics of pomegranate cvMalase-Saveh. World of Sciences J., 4: 179-187.

Davarpanah, S.; Tehranifar, A.; Davarynejad, G.; Abadia, J. and Khorasani, R. (2016). Effect of foliar application of zinc and boron nano-fertilizers on pomegranate (Punica granatum cv. Adrdestani) fruit yield and quality. Scientia Horticulturae, 210: $1-8$.

Davis, J. M.; Sanders, D. C.; Nelson, P. V.; Lengnick, L. and Sperry, W. J. (2003). Boron improves growth, yield, quality, and nutrient content of tomato. J. Amer. Soc. Hort. Sci., 128 (3): 441446.

Delgado, R.; González, M. and Martín, P. (2006). Interaction effects of nitrogen and potassium fertilization on anthocyanin composition and chromatic features of Tempranillo grapes. International J. Vine \& Wine Science, 40: 141-150.

El-Kady, H.F.M. (2011). Productive performance of Thompson seedless grapevines in relation to application of some antioxidants, magnesium and boron. M.Sc. Theses Fac. Agric. Minia Univ. Egypt.

Ganeshamurthy, A.N.; G.C. Satisha and P. Patil (2011). Potassium nutrition on yield and quality of fruit crops special emphasis on banana and grapes. Karnataka J. Agric. Sci., 24(1): 29-38.

Geza, H.; Parsons,G. F. and Mattick, L. R. (1983). Physiological and biochemical events during development and maturation of grapes berry. Amer. J. Enol. Vitic., 35 (4): 220-227.

Hamouda, H.A.; Abdel Motty, E.Z. and Zahran, N.G. (2015). Nutritional status and improving fruit quality by potassium, magnesium and manganese foliar application in pomegranate shrubs. International J. Chem. Tech., 8 (6): 858-867. 
Havlin, J.L.; Beaton, J.D.; Tisdale, S.L, and Nelson, W.L. (2005). Soil fertility and fertilizers: A International to Nutrient Management. $7^{\text {th }}(\mathrm{Ed})$. Pearson Prentice Hall. New Jersey.

Hunsche, M.; Brackmann, A. and Ernani, P.R. (2003). Effects of $\mathrm{K}$ fertilization on the post-havest quality of 'Fuji' apples. Brazilian Journal of Agricultural Research, 38: 489-496.

Ibrahim, H.I.M. and Al-Wasfy, M.M. (2014). The promotive impact of using silicon and selenium with potassium and boron on fruiting of Valencia orange trees grown under Minia region conditions. World Rural Observations, 6(2): 28-36.

Ju, Z.; Duan, Y. and Ju, Z. (1999). Effects of covering the orchard floor with reflecting films on pigment accumulation and fruit coloration in 'Fuji' apples. Scientia Horticulture, 82: 47-56.

Kahayyat, M.; Tehanifar, A.; Zaree, M.; Karimian, Z.; Aminifard, M.H. and Vazifeshenas, M.R. (2012). Effect of potassium nitrate spraying on fruit characteristics of Malas Yazdi pomegranate. J. Plant Nutrition, 35 (9): 13871393.

Khalil, H.A. and Aly, H.S.H. (2013). Cracking and fruit quality of pomegranate (Punica granatum L.) as affected by pre-harvest sprays of some growth regulators and mineral nutrients. J. Hort. Sci. \& Ornament. Plants, 5 (2): 71-76.

Kow, N. and Nabwami, J. (2015). A review of effect of nutrient elements on crop quality. African J. Agric. Nutrition \& Develop., 15 (1): 9777- 9793.

Kumar, A.R.; Kumar, N. and Kavino, M. (2006). Role of potassium in fruit crops - a review. Agric. Rev., 27(4):284 - 291.

Lalet, S.; Ahmed, N. and Mir, J.I. (2011). Effect of different chemicals on fruit cracking pomegranate under Karewa conditions of Kashmir valley. J. Plant Physiol., 16 (3\&4): 326-330.

Lavon, R. and Goldschmidt, E.E. (1996). Potassium deficiency and carbohydrate metabolism in citrus. pp. 101-109. In: Frontiers in potassium nutrition: new perspectives on the effect of potassium on physiology of plants. (Eds. D.M. Oosterhuis and G.A. Berkowitz). Indianapolis, IN, USA.

Marschner, H. (1995). Mineral nutrition of higher plants, Academic Press, ISBN: 0124735436.

Marschner, H. (1997). Mineral nutrition of higher plants. Second Edition, Paston press Ltd, Londdon, New York. pp 889.

Meena, D.; Tiwari, R. and Singh, O.P. (2014). Effect of nutrient spray on growth, fruit yield and quality of aonla. Annals Plant \& Soil Res., 16 (3): $242-245$
Mehta, B. (2012). Effect of pre harvest foliar sprays of boron and retain for improvement of quality parameters of apricot (Prunus armeniaca L.) in Tasmania. Ph.D. of plant physiology, University of Tasmania, Australia.

Mengel, K (1985). Dynamics and availability of major nutrients in soil. Advances in soil Sci., 2, Springer-Verlag New York, Increase. pp 89-91.

Mengel, K. (2007). Potassium, in: Barker A.V., Pilbeam D.J editors. Hand book of plant nutrition. $1^{\text {st }}$ ed. Boca Raton, FL.USA: CRC/ Taylor and Francis, pp. 91-116.

Messaoudi, Z.; Il-Idrissi, Z. and Khatib, F. (2012). Effets de quelques pulvérisation foliaires sur l'éclatement des grenades sous les conditions du Tadla (Maroc). II International symposium on the pomegranate, Options méditerranéennes. Series A: Mediterranean Seminars, 2012- Number 103: pp 155-158.

Mohamed, R.A.M. (2014). Studies on the effect of spraying potassium silicate and vitamin B on fruiting of Manfalouty pomegranate trees. M.Sc. Theses Hort. Depart. Faculty of Agric. Minia Univ.

Moor, U.; Poldma, P.; Tonutare, T.; Karp, K.; Starast, M.E. and Vool, E. (2009). Effect of phosphite fertilization on growth, yield and fruit composition of strawberries. Scientia Horticulture, 119: 264-269.

Mpelasoka, B.S.; Schachtman, D.P.; Treeb, M.T. and Thoas, M.R. (2003). A review of potassium nutrition in grapevines with special emphasis on berry accumulation. Australian J. Grape \& Wine Res., 9: 154-168.

Omar, M.O.A. (2014). Selecting the best N, P and $\mathrm{K}$ level for Wonderful pomegranates trees grown under Minia region. M.Sc. Thesis. pp 102. Hort. Department Fac. Of Agric. Minia University. Egypt.

Omar, M.O.A. (2015). Selecting the best N, P and $\mathrm{K}$ level for Wonderful pomegranates trees grown under Minia region. M.Sc. Thesis. pp 102.

Parvin, M.; Ziaeyan, A.; Dastfal, M. (2017). Combined effects of mycorrhiza, organic fertilizers, and potassium application on yield and quality of pomegranate (Punica granatum L.) fruit. J. Biological Chemistry, 31 (3): 329-338.

Ranganna, S. (1977). Manual analysis of fruit and vegetable products. Edition Tata Mc Grow-Hill Publishing Company, New Delhi India, 634 P.

Salama, M.I.; El-Morsi, A.K.O. and El-Basyoni, R.I. (2016). Improving yield and fruit quality of Wonderful pomegranates using bagging and potassium treatments under Kafre El-Sheikh conditions. J. of Plant production, Mansoura Univ., 6 (1): $210-217$ 
Samaranayake, P., Peiris, B.D. and Dssanayake, S. (2012). Effect of excessive ferrous $\left(\mathrm{Fe}^{2+}\right)$ on growth and iron content in rice (Oryza sativa). Int. J. Agri. Biol., 14: 296-298.

Sharma, N. and Belsare, C. (2011). Effect of bioregulators and nutrients on fruit cracking and quality in pomegranate (Punica granatum L.), G-137 in Himachal Pradesh. Acta Hort. 890: 347-352.

Sharma, P.; Singh, A.K. and Sharma, R.M. (2005). Effect of plant bio regulators (PBRS) and micronutrients on fruit set and quality of litchi cv. Dehradun. Indian J. Hort., 62 (1): 24-26.

Shear, C. B. and Faust, M. (1971). Nutritional factors influencing the mineral content of apple leaves. J. Amer. Soc. Hort. Sci., 96: 234-240.

Sheikh, M.K. and Manjula, N. (2012). Effect of chemicals on control of creaking in pomegranate (Punica granatum L.) var. Ganesh. Option Méditerranéennes, A, no. 103, 2012. II International Symposium on the Pomegranate. Pages 133-135.

Singh, D.K.; Paul, P.K. and Ghosh, S.K. (2005). Response of papaya to foliar application of boron, zinc and their combinations. Res. Crops, 6 (2): 277 280.

Singh, J. and Maurya, A.N. (2004). Effect of micronutrients on bearing of mango (Mangifera indica) cv. Mallika. Prog. J. Agri., 4 (1): 47-50.

Snedecor, G. W. and W. G. Cochran. (1980). Statistical Methods. Oxford and J.B.H. publishing com. $7^{\text {th }}$ edition, 593 p.

Sparr, M. (1970). Micronutrient needs-which, where, on what-in the United States. Communications in Soil Science \& Plant Analysis, 1(5), 241-262.

Sumam, M.; Sangma, P.D. and Singh, D. (2017). Role of micronutrients (Fe, $\mathrm{Zn}, \mathrm{B}, \mathrm{Cu}, \mathrm{Mg}, \mathrm{Mn}$ and $\mathrm{Mo}$ ) in fruit crops. International J. Current Microbiology \& Applied Sciences, 6, (6): 32403250 .

Tagliavini, M., Abadía, J., Rombolà, A.D., Abadía, A., Tsipouridis, C. and Marangoni, B. (2000). Agronomic means for the control of iron deficiency chlorosis in deciduous fruit trees. J. Plant Nutr., 23: 2007-2022.

Tehranifar, A and Tabar, S.M. (2009). Foliar application of potassium and boron during pomegranate (Punica granatum) fruit development can improve fruit quality. Horticulture Environment and Biotechnology, 1. 19.

Walsh, L.M. and Beaton, J.D. (1986). Soil testing and plant analysis. $6^{\text {th }}$ edition. Editor, Soil science society of America, Inc. pp 489.
Wassel, A.H.M.; Ibrahim, H.I.M. and Shaaban, M.M. (2015). Response of Wonderful pomegranate trees to foliar application of amino acids, vitamins B and silicon. World Rural Observation, 7 (3): 92-95.

Zhang, C. and Whiting, M.D. (2011). Improve Bing sweet cherry fruit quality with plant growth regulators. Scientia Horticulturae, 127: 341:346.

Zuo, Y. and Zhang, F. (2011). Soil and crop management strategies to prevent iron deficiency in crops. Plant Soil, 339: 83-95. 